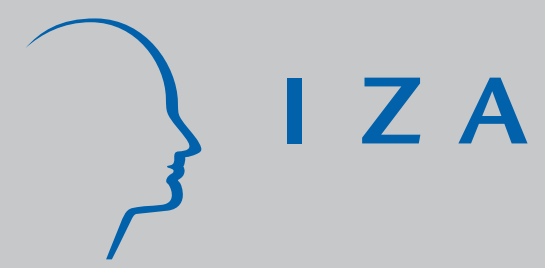

IZA DP No. 9059

Power-Couples and the Colocation Hypothesis Revisited

Francesco Mariotti

Karen Mumford

Yolanda Pena-Boquete

May 2015 


\title{
Power-Couples and the Colocation Hypothesis Revisited
}

\author{
Francesco Mariotti \\ University College London \\ Karen Mumford \\ University of York \\ and IZA \\ Yolanda Pena-Boquete \\ University of Vigo
Discussion Paper No. 9059
May 2015 \\ IZA \\ P.O. Box 7240 \\ 53072 Bonn \\ Germany \\ Phone: +49-228-3894-0 \\ Fax: +49-228-3894-180 \\ E-mail: iza@iza.org
}

Any opinions expressed here are those of the author(s) and not those of IZA. Research published in this series may include views on policy, but the institute itself takes no institutional policy positions. The IZA research network is committed to the IZA Guiding Principles of Research Integrity.

The Institute for the Study of Labor (IZA) in Bonn is a local and virtual international research center and a place of communication between science, politics and business. IZA is an independent nonprofit organization supported by Deutsche Post Foundation. The center is associated with the University of Bonn and offers a stimulating research environment through its international network, workshops and conferences, data service, project support, research visits and doctoral program. IZA engages in (i) original and internationally competitive research in all fields of labor economics, (ii) development of policy concepts, and (iii) dissemination of research results and concepts to the interested public.

IZA Discussion Papers often represent preliminary work and are circulated to encourage discussion. Citation of such a paper should account for its provisional character. A revised version may be available directly from the author. 
IZA Discussion Paper No. 9059

May 2015

\section{ABSTRACT}

\section{Power-Couples and the Colocation Hypothesis Revisited ${ }^{\star}$}

We analyse the migration movements of power couples (couples where both members have at least a college degree), half power and no-power couples within Australia. We explicitly allow for potential correlation of these movements with local labour market features. Our results support the urbanisation hypothesis for ongoing couples over either the colocation or tied-mover models. Partnered college graduates like to live in major cities regardless of their gender or the qualifications of their partner.

JEL Classification: J3, J7

Keywords: gender, graduates, colocation, tied-mover, urbanisation, migration, power couples

Corresponding author:

Karen Mumford

Department of Economics and Related Studies

University of York

Heslington

York YO10 5DD

United Kingdom

E-mail: karen.mumford@york.ac.uk

\footnotetext{
* This paper uses unit record data from the Household, Income and Labour Dynamics in Australia (HILDA) Survey. The HILDA Project was initiated and is funded by the Australian Government Department of Social Services (DSS) and is managed by the Melbourne Institute of Applied Economic and Social Research Melbourne Institute). The findings and views reported in this paper, however, are those of the authors and should not be attributed to either DSS or the Melbourne Institute. We thank the HILDA data providers. Research on this paper was carried out whilst Karen Mumford held Visiting Fellowships at the Melbourne Institute of Applied Economic and Social Research (MIAESR) and the Centre for Applied Macroeconomic Analysis (CAMA); their hospitality is gratefully acknowledged.
} 


\section{Introduction}

In their seminal study of family migration patterns, Costa and Kahn (2000) show that an increasing proportion of America's power-couples (couples where both spouses are college educated to at least Bachelor level) were found in large metropolitan areas between 1940 (when 32 per cent were) and 1990 (when 50 per cent were). Costa and Kahn (2000) argue that this geographical shift for power-couples is predominantly due to the greater probability of a successful labour market match for both spouses that larger metropolitan labour markets offer. In their model, power-couples are viewed as dual career households in the sense that both household members aspire to their own careers (Polacheck and Horvath, 1977; Mincer, 1978). If power-couples are joint decision makers, they face the difficulty of finding jobs that match the skills of each spouse within a reasonable distance from their mutual home. This may lead power-couples to concentrate in large metropolitan areas where there are more potential job matches. Increases in the rates of college education and labour market participation amongst women (Goldin and Katz, 2009) exacerbate this matching requirement, increasing the polarity across family education patterns found for metropolitan and rural areas. Costa and Kahn (2000) refer to this as a "colocation" phenomenon.

The issue of whether power-couples actually migrate into large metropolitan areas (LMAs) is not easily addressed by the cross sectional census data used by Costa and Kahn (2000). Using longitudinal panel data, Compton and Pollak (2007) further explore the migration patterns of power-couples and conclude that colocation is not the dominant explanation of movement into LMAs in America. They argue that when couples do migrate, it is the education level of the husband which best predicts this

propensity to migrate regardless of the education of the wife; implying that women are passive (or "tied-movers") rather than equal in the migration decision.

If women recognise that they will be tied-movers, they would respond by seeking qualifications which are general rather than specific in nature (Becker, 1962 and 1964) allowing them greater geographical mobility and firms will be less likely to offer then training incorporating job specific skills. If women further believe that they will face a wage cut when migrating with their partner (Blackburn, 2010), they may engage in less education resulting in gender based productivity and earning differentials (Compton and Pollak, 2007; page 479). 
An alternative explanation for the relative relocation of power-couples may simply be that the college educated are more mobile (Greenwood, 1997) and will tend to migrate into large metropolitan areas as they are attracted by the extra facilities available there. This "urbanisation" results in a larger pool of the college educated in metropolitan areas over time.

A comparison of the three models suggests a simple test: colocation predicts that power couples will be significantly more likely to migrate into major cities than any other couple type; the female tied-movers hypothesis predicts that the probability of migrating into large cities will be higher for couples where the male is a college graduate (i.e., power couples or male half-power couples); and urbanisation implies power-couples and half-power couples (regardless of the gender of the graduate) will be more likely to migrate to large cities than no-power couples (those where neither partner is a college graduate).

Australia is particularly suitable for such a study: it has one of the highest internal migration rates amongst stable economies (Hugo and Harris, 2011; page 15) and a considerable proportion of its population live in urban areas. ${ }^{1}$ Our contribution is to enrich this still unresolved area of research by investigating internal migration movements of power-type couples within Australia with a particular focus on the potential association between migration and local labour market features. In the process, we address whether colocation, tied-moving or urbanisation best describes the internal migration patterns for Australian couples.

We believe that this is the first study of this nature carried out in the Australian context. Data and variable selection are discussed in the next section, estimation methods and results are presented and discussed in section 3, with conclusions provided in section 4.

\footnotetext{
${ }^{1}$ In 2014, 89 per cent of Australia's population were urban compared to 81 per cent in the United States, 86 per cent in New Zealand, 88 per cent in Denmark and 92 per cent in Israel (Central Intelligence Agency, 2014).
} 


\section{The migration patterns of couples in Australia}

The data are taken from the Household, Income and Labour Dynamics (HILDA) ${ }^{2}$ survey which is a nationally representative, annual sample of private Australian households. The HILDA survey was launched in 2001. Each year, individual adult members (those aged 15 years and over) of households are interviewed over a broad range of socioeconomic topics; with particular emphasis on income, labour market characteristics, and family formation. (For greater detail on the HILDA survey design see Summerfield et al., 2013).

We make use of seven waves of the HILDA data (waves 2 to 8 ). The first wave is excluded due to a lack of data on pertinent variables. ${ }^{3}$ Whilst Australia was slow to respond to the recent international financial crises, 2009 saw a global recession (IMF, 2009; pages 11-14) and a substantial growth in unemployment (Junankar, 2014), the time period of interest has been accordingly limited to 2008. The sample is also restricted to couples whose average age is 50 or less as it is plausible to assume that these couples are more inclined to move for career reasons than are older households closer to retirement age. ${ }^{4}$ These sampling restrictions and those associated with the explanatory variables leads to the identification of 10,184 couple observations.

The couples are divided into four categories based on the education levels of the members: "power" couples (both couple members have at least a college, defined as Bachelor or higher level, degree); "male" or "female-power" couples (the male or female partner, respectively, has at least a college degree); and "no-power" couples (neither of the partners has a college degree). Table 1 reports the distribution of the 10,184 sample units across the four couple categories. We can see that of the 10,184 couples in the sample, 1,786 (or 17.5 per cent of the total) are power couples, of these 171 couples migrated (or 9.6 per cent of the 1,786 power couples).

\footnotetext{
${ }^{2}$ This paper uses unit record data from the Household, Income and Labour Dynamics in Australia (HILDA) Survey. The HILDA Project was initiated and is funded by the Australian Government Department of Social Services (DSS) and is managed by the Melbourne Institute of Applied Economic and Social Research Melbourne Institute). The findings and views reported in this paper, however, are those of the authors and should not be attributed to either DSS or the Melbourne Institute.

${ }^{3}$ For example, information on home ownership was only collected from the second wave, this variable is used as a control variable in the estimation.

${ }^{4}$ The same analysis was repeated for couples with an average age of 40 or less and confirms the results obtained with the older couples. Results are available on request.
} 
Table 1. Couple power-types

\begin{tabular}{|c|c|c|c|c|}
\hline & \multicolumn{2}{|c|}{ All } & \multicolumn{2}{|c|}{ Migrated } \\
\hline & Freq. & Perc. & Freq. & Perc \\
\hline & (1) & (2) & (3) & (4) \\
\hline Power couples & 1786 & 17.5 & 171 & 9.6 \\
\hline Male-power couples & 1022 & 10.0 & 85 & 8.3 \\
\hline Female-power couples & 1545 & 15.2 & 143 & 9.3 \\
\hline No-power couples & 5831 & 57.3 & 397 & 6.8 \\
\hline Total & 10184 & 100 & 796 & 7.8 \\
\hline
\end{tabular}

Source: HILDA Survey - Waves 2 to 8 (Pooled)

The term "migration" is used in this work to identify a change in Local Government Area (LGA) residency. Restricted data available in the HILDA Inconfidence Release files provide the geographical identification of households at a LGA level. A LGA represents the third and lowest tier of government in Australia, there are 565 LGAs in Australia. ${ }^{5}$ Information on LGAs was combined with information on the Section of State (SOS) which enables grouping into three broad types: major city, urban or rural. The joint use of LGAs and SOS leads to the identification of migration movements and type of place of destination and origin. Migration is relatively common in the sample, columns 3 and 4 of Table 1 reveal that 796 (or 7.8 per cent) of the couples migrated between 2002 and 2008.

Figure 1 reports the overall geographical distribution of couples by power-type and by type of location. Living in a major city is clearly the most common outcome for all of the couple types, more so for the power couples. There is also prima facie evidence that male-power couple outcomes have a more similar geographical distribution to power couples than do female-power couples.

\footnotetext{
${ }^{5}$ LGAs are often referred to with different names. This is because the name "local government area" is used to identify a geographical area under the responsibility of an incorporated local government council. The range of local government councils varies across states. The types of LGAs in each state are: Cities, and Areas (New South Wales); Cities, Rural Cities, Boroughs and Shires (Victoria); Cities, Towns, and Indigenous Councils (Queensland); Cities, Rural Cities, Municipalities and District Councils (South Australia); Cities, Towns and Shires (Western Australia); Cities and Municipalities (Tasmania); Cities, Towns, Shires and Community Government Councils (Northern Territory).
} 


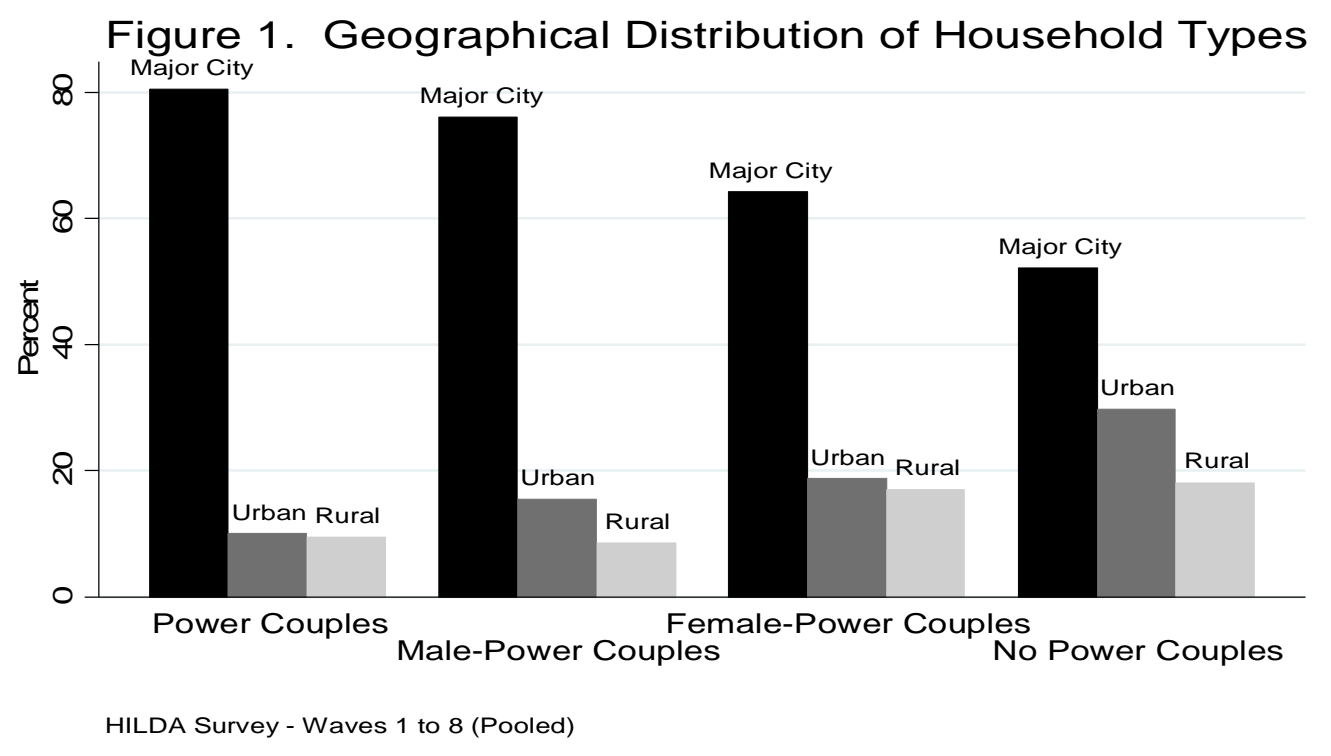

Figures 2 and 3 focus on those couples who have migrated. Figure 2 reports the distribution of migration destinations across couple power-types by distinguishing destination locations by type.

Figure 2. Migration Destination by Household Types

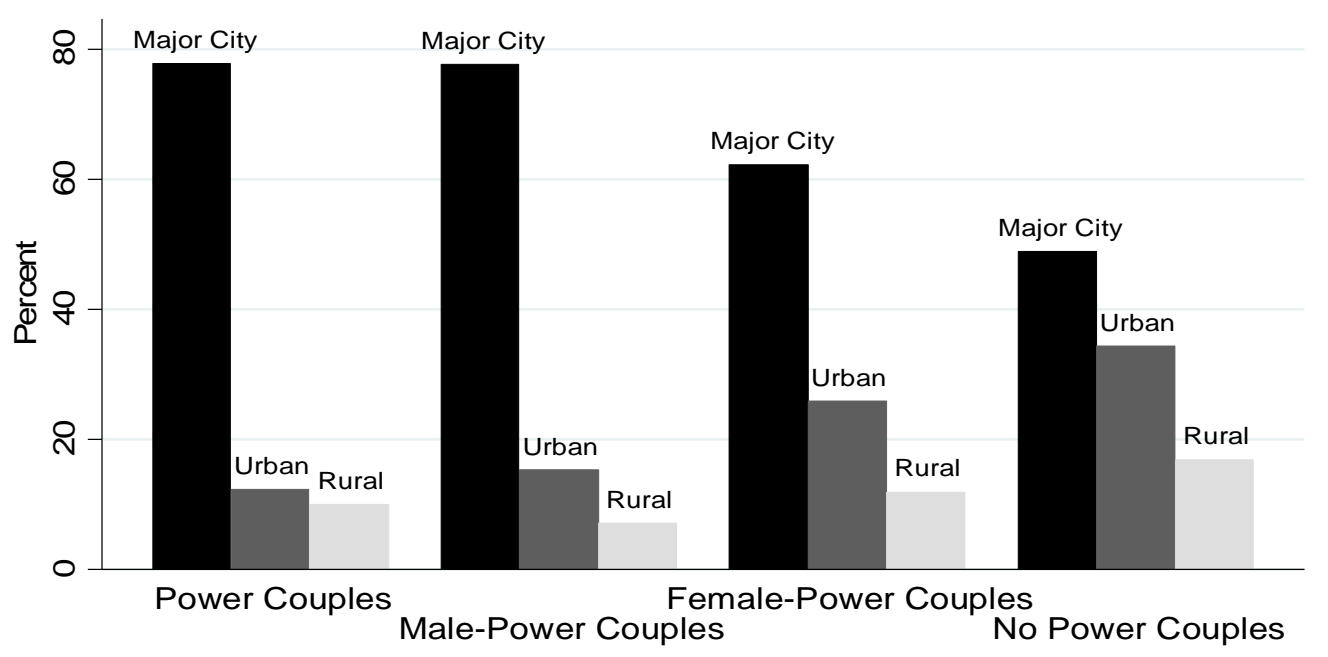

HILDA Survey - Waves 1 to 8 (Pooled)

It is clearly considerably more common for power and half-power couples to migrate to major cities than to urban and rural areas combined. This trend is also true for no-power couples, however, their migration movements are more strongly directed 
to urban and rural locations. The migration movements of male-power couples can again be seen to follow the migration patterns of power couples more closely than female-power couples, which in turn, are more similar to the migration patterns of nopower couples.

Figure 3 reports the distribution of places of origin across couple power-types by distinguishing origin locations by type. The trends reported in the Figure 3 are very similar to those reported in Figures 1 and 2: migration movements of power-type couples seem to be clustered on location type; power and half-power couples tend to migrate between major cities. Migration movements of no-power couples show considerably stronger tendencies to also move to and from urban and rural areas. Male-power couples again appear to behave more like power couples whilst femalepower couples appear more like no-power couples.

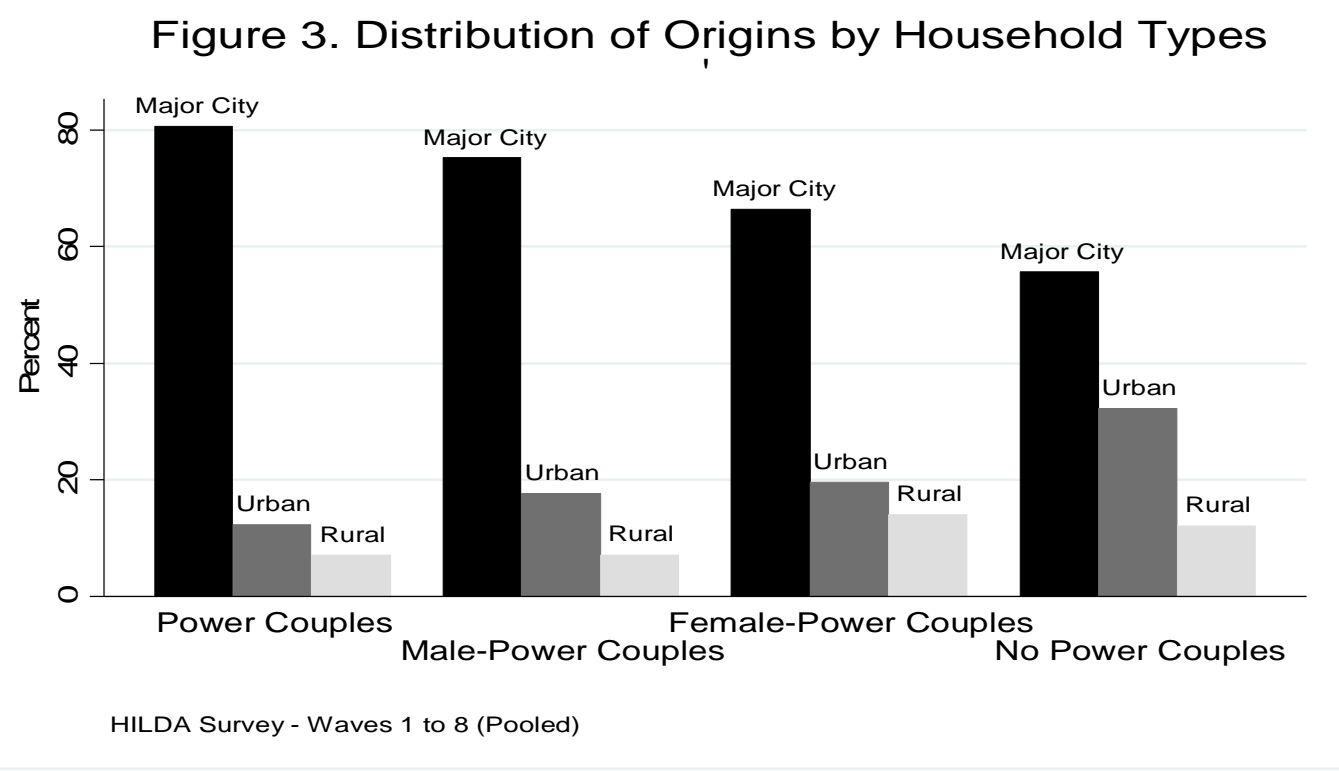

If power couples were subject to colocation pressure, their migration patterns would be different from the migration patterns of the other power-type couples. Instead, the preliminary evidence on the migration patterns of power couples and male-power couples revealed in Figures 1 to 3 does not support the colocation hypothesis proposed by Costa and Kahn (2000) and may instead reflect the argument that females are tied-movers as presented by Compton and Pollack (2007). We return to test these hypotheses more formally in the estimation section below. 
We are interested in the migration movements of power-type couples within Australia with a particular focus on the potential association between these movements and local labour market features. Couple power type, geographic area, and migration are defined and discussed above.

Table 2 presents selected summary statistics for the variables and samples of interest. The table contains five columns for the full sample, power couples, malepower, female-power, and no-power couples, respectively. Beginning with the full sample of all couples in panel 1 of Table 2, males (panel 1) and females (panel 2) can be seen to have similar education (both genders having on average close to 13 years of education). We assume individuals judge whether they are over or under-educated by comparing their own education (measured in years) with the local area (LGA) average education for their occupation. If the individual is not employed, she/he is assumed to compare their education level to the average education of those not-in-employment in their LGA. These relative education measures are constructed for the two genders separately; the female member of the couple compares herself with the local female labour force and similarly the male member of the couple compares himself with the local male labour force. Overall (see Table 2), females tend to be over-educated relative to males although there is substantial variance in the measure. When the analysis is restricted to power-type couples, the power-members of the couples are typically over-educated and the no-power member under-educated, analogously both couple members are on average under-educated in no-power couples (column 5).

The LGA unemployment rate is included as an indicator of local labour market tightness. This measure is also constructed for the two genders separately. Perhaps unsurprisingly, this measure of unemployment is similar for the two genders, being slightly less for power couples than for no-power couples. A further indicator of labour market tightness is provided by constructing the measure of local labour market job insecurity. A particularly attractive characteristic of the HILDA survey is the presence of subjective job insecurity information. The respondent is asked the following question: What do you think is the per cent chance that you will lose your job during the next 12 months? (That is, get retrenched or fired or not have your contract renewed). A value of 0 indicates the individual is certain of retaining their job, whereas a value of 100 suggests the individual is certain of losing his/her job in the next 12 months. Local market job insecurity was constructed by taking the average of this subjective job insecurity measure at LGA level for the two genders 
separately. As shown in Table 2, on average males report a slightly more insecure local labour market than females and this is true for all couple types (considering columns 1 to 5, inclusively).

Table 2 also reports labour force status for males and females across powertype couples. Employment rates are considerably higher for males at 93 per cent for all males and 73 per cent for all females. The biggest employment difference across couple members occurs amongst male-power couples (97 percent of the men and 68 per cent of the women employed). In general, the gender employment rates are similar for power couples and female-power couples, whilst no-power couples also have considerable fewer women employed. In aggregate, unemployment rates are considerably lower amongst power couple members than no-power couples. A similar pattern is found for the percentage out-of-the-labour-force; men are consistently found to be more likely to be participating in the labour market, with the gender gap in participation being highest in male-power couples (followed closely by no-power couples).

Considering household characteristics (panel 3 of Table 2), the average age distribution across couples is similar with no-power couples averaging the youngest at 35.3 years and male power couples the oldest at 37.3. On average, the households in the full sample have 1.3 dependent children present (column 1, panel 3), this is closer to 1.1 dependent children when the female couple member is a graduate. Household financial year disposable income is calculated as the difference between household financial year gross incomes (including wages, windfall and other income) less all household financial year taxes. It is measured in 2006 Australian dollars. Power couples have 56 per cent more disposable income than no-power couples in Australia. The female household disposable income share is measured as the female partner's individual contribution to her total household's disposable income. The share of household income controlled by the female is on average 32 per cent (or some half of the share generally controlled by the male). ${ }^{6}$ This value varies between 24 per cent in male-power couples to 41 per cent for female-power couples (panel 4). ${ }^{7}$ A substantial

\footnotetext{
${ }^{6}$ Men earn substantially more per hour than women in Australia, our data indicates a raw average hourly gender wage gap of 28.5 per cent (this gap is consistent with other studies using Australian data, see Chzhen et al 2013).

${ }^{7}$ Akerlof and Kranton (2000 and 2010) and Bertrand et al (2015) argue that couples seek traditional roles with respect to the control of household resources, in particular, couples may reject labour market outcomes which result in women earning more than their male partners and/or that households display an aversion to women having higher incomes than their partners.
} 
proportion of the couple members are foreign born, considerably more so amongst nopower couples. Finally, home ownership is prevalent in Australia (Mariotti et al, 2015) and the distribution of home ownership across power-type couples is consistent with expectations: no-power couples are considerably less likely to be home owners. We would expect home-ownership to increase the costs associated with migration and to lessen the probability of the couple moving.

\section{Estimation and results}

Similar to Compton and Pollak (2007), we estimate two econometric models of migration. ${ }^{8}$ The first model estimates the probability of migrating allowing for sample selection:

$$
\begin{aligned}
& q_{i t}^{*}=z_{i t} \delta+v_{i t} \quad i=1, \ldots, N_{1} \text { and } t=1, \ldots, T \\
& y_{i t}^{*}=x_{i t} \beta+u_{i t} i=1, \ldots, N_{2}, N_{2}<N_{1} \text { and } t=1, \ldots, T
\end{aligned}
$$

where equation (1) estimates the probability of remaining in the sample, $q_{i}^{*}$; and equation (2) estimates the probability of migrating $y_{i}^{*} ; z_{i t}$ and $x_{i t}$ are vectors of exogenous explanatory variables; $\delta$ and $\beta$ are the corresponding vectors of parameters to be estimated; and $v_{i t}$ and $u_{i t}$ are error terms; $N_{1}$ denotes the full sample; $N_{2}$ includes all the couples that survive (e.g. couples that remain together or couples that decide to keep participating in the survey). Sample attrition can be considered by rewriting equation (2):

$$
y_{i t}^{*}=x_{i t} \beta+\lambda\left[\frac{\phi\left(z_{i t} \delta\right)}{\Phi\left(z_{i t} \delta\right)}\right]+\eta_{i t}, i=1, \ldots, N_{1}, \text { and } t=1, \ldots, T
$$

\footnotetext{
${ }^{8}$ In Compton and Pollak (2007) the migration decision is defined in terms of a three equation latent dependent variable model (rather than the two equation model presented here), the third equation estimates the probability the coupling continuing (not divorcing).. The divorce equation cannot be estimated with the HILDA dataset that we use as it is not possible to identify why sample units disappear from the survey.
} 
replacing $v_{i t}$ with the estimated generalised residuals from the probit model, (shown by Vella (1993) to be equal to their respective inverse Mills ratio); the $t$-test on $\lambda$ is a test of attrition.

In the second model, the decision to migrate (or not) is modelled simultaneously with the type of place of destination (Compton and Pollak, 2007; page 485). The probability that observation $i$ chooses outcome $j$ is given by:

$$
\begin{aligned}
& \mathrm{P}(y=1 \mid \mathbf{x})=1 /\left[1+\sum_{h=1}^{J} \exp \left(x_{i t} \beta_{h}\right)\right], j=1 \\
& \mathrm{P}(y=j \mid \mathbf{x})=\exp \left(x_{i t} \beta_{h}\right) /\left[1+\sum_{h=1}^{J} \exp \left(x_{i t} \beta_{h}\right)\right], j=2,3,4
\end{aligned}
$$

where $j=1,2,3,4$ represents the four destination outcomes (not migrating $j=1$, migrating to rural $j=2$, urban $j=3$, or major city $j=4$ location, respectively). The baseline category, chosen for the multinomial logit model, is not migrating.

\section{(i) Model 1, the migration decision}

We begin with a base model for the probability of the couple migrating, corresponding to equation (3). The explanatory variables included in the base model are: the type of power coupling (omitted category is no-power); the type of the LGA (omitted category is major city); the age (and age squared) of each couple member; each couple member's education relative to the LGA average for their occupation; the number of dependent children in the household, least one couple member being foreign born, and if the couple are home owners. Full results for the base model are provided in Table 3 with: no correction for attrition in column 1; IMR correction in column 2 (Vella 1998) ${ }^{9}$; or inverse probability weighting IPW in column 3 (Robins et

\begin{tabular}{lcrrr}
\hline \multicolumn{1}{l}{ Inverse Mills Ratio } & & & & \\
\hline \hline & Mean & St. Dev & Min & Max \\
$\phi\left(z_{i t} \delta\right) / \Phi\left(z_{i t} \delta\right)$ & 0.299 & $0 . .227$ & 0 & 1.585 \\
\hline \hline HILDA Survey - Waves 2 to 8 (Pooled) & & &
\end{tabular}

The vector $z_{i t}$ in equation (1) includes the base model variables and each couple member's own health status (a binary measure coded as 1 if the individual records their health as fair or poor, as opposed to being good, very good or excellent). Sample attrition is found to be relevant and should be addressed when considering coupled migration within Australia (as indicated by the significant Inverse Mills Ratio in the penultimate row of Table 4). 
al. 1995) ${ }^{10}$. We did not find significantly different results adopting IPW and instead adopt IMR correction (which was found to be significant) in the analyses below. Whilst we discuss selected results from the base model in more detail shortly, it is worth noting that we find that couples are less likely to migrate if the male is overeducated or if the couple own (purchased or currently paying a mortgage on) their house across the three specifications in Table 3.

Table 4 presents selected marginal effects from the probit estimation of the probability of migrating with IMR correction; corresponding to equation (3) and the base model presented in column 2 of Table 3. The results presented in column (A) of Table 4 reveal that power couples are 4.3 per cent more likely to migrate than nopower couples, male power couples are 3.7 per cent more likely and female power couples are only 3 per cent more so. These differences in rank are not significant (at standard confidence levels). However, the relationship between female power couples and migration is strongly significant in its own right. Moving across the columns in Table 4, alternative explanatory variables are added to the model and the marginal effects associated with these variables are reported. Column B considers job insecurity in the local labour market of origin, Column $\mathrm{C}$ the local unemployment rate and column D considers labour market status, household disposable income, and the female income share. In each case, it is typically the female measure (rather than the male) that is found to be significantly related with migration. The final rows of column D suggest that couples with higher household income are more likely to migrate whilst female income share is not significantly relevant. Importantly, changing the specifications as we move across the columns in Table 5 is not associated with substantial or significant changes in the marginal effect of power couple status on the probability of migrating.

To reiterate, we do not find prima facie evidence suggesting females are tiedmovers in migration decisions from Table 4. Power couples do appear to be the most likely to migrate, however, unlike Compton and Pollack (2007) we do not find this

\footnotetext{
${ }^{10}$ We considered sample attrition correction based on Inverse Probability Weighting (IPW) which can be applied to general $M$-estimators (Robins et al. 1995; Fitzgerald et al. 1998, 1999; Wooldridge 2002a, 2002b). This approach can be applied in the context of inherently non-linear models (such as probit). From the first stage probit estimation represented by equation (1), the fitted probabilities of estimated response $p_{i t}$ are obtained. The inverse of the fitted probabilities are used to weight the observations in the IPW models. The observations appearing for the first time in the sample are attached a $p=1$ (a trivial interpretation is that sample units appearing for the first time in the sample are certain to be in their respective waves). Results are presented in column 3 of Table 3 for the base model.
} 
relationship is significantly stronger for male half power couples than for female half power couples.

We also do not find significant differences in the probability to migrate related to the type of the origin LGA. The statistical insignificance of the parameter estimates associated with the labour market composition of the place of origin provides some support for the prediction of Costa and Kahn (2000).

\section{(ii) Model 2, migration and destination determined together.}

Table 5 presents selected results for the multinomial logit estimation of the probability of migrating to major city (column 1), urban (column 2) or rural (column 3) destinations relative to not migrating for the base model. ${ }^{11}$ Relative risk ratios are recorded in italics, followed by the respective coefficient estimate and standard error. The panels in Table 5 correspond to the columns in Table 4, so panel A of Table 5 provides results for the equivalent model in column A of Table 4; panel B of Table 5 for column B of Table 5, and so on.

The selected results presented in column 1 of panel A of Table 5 reveal that power-couples are 2.1 times more likely to migrate to a major city relative to the omitted no-power couples; male-power couples are 2.0 times more likely; and femalepower couples are 1.7 times more likely. However, the estimated coefficients underlying these relative risk ratios are not significantly different to each other. Reading across the columns in panel A reveals that the significant relationship (and the qualitative ranking) between migration probability and power-type is only found for migration into major city LGAs, There are no significant associations found for couple power-type and the probability to migrate to urban or rural LGAs.

Considering the type of the origin LGA in column 1, (compared to the omitted urban LGA), couples are more likely to migrate to major city LGAs if they come from a major city LGA already. They are less likely to migrate from a major city LGA to an urban LGA (column 2) or to a rural LGA (column 3).

Similar results are found in panel B when the gender specific labour market insecurity measure of the origin LGA is included in the analysis; in panel $\mathrm{C}$ when the gender specific unemployment rate in the origin LGA is included; and in panel D

\footnotetext{
${ }^{11}$ Table A1 of the Appendix provides full results for the base model multinomial logits corresponding to panel A of Table 5: couples are again found to be less likely to migrate if the male is over-educated (although not significantly for migration into a major city LGA) or if the couple own (purchased or currently paying a mortgage on) their house.
} 
when individual labour market status, household disposable income and female couple member's share of household income are reported.

Taken together, our results suggest that couples with at least one graduate member are more likely to migrate to major city LGAs regardless of the gender of the graduate. When they migrate, they tend to move from major city LGA to major city LGA.

The results in Table 5 also indicate that when the probability of migration is associated with gender specific variables, these tend to be the female measures. For example, the probability of migrating to an urban area is significantly lower when women report more local labour market insecurity, although with a relative risk ratio of 0.966 this effect is very small (panel B); the probability of the couple migrating to an urban or rural type LGA is strongly related to the LGA unemployment rate for females (panel C); and there is a higher probability of the couple migrating to major city or urban LGAs when the female is unemployed or out-of-the-labour market (panel D).

Rather than being a tied-mover, we could interpret these findings as suggesting that females who are not well matched in the local labour market are successfully migrating the couple. Alternatively, the couple are more likely to migrate when the female's labour market position is tenuous. It is only in column 3 of panel D that we find a significant relationship between migration and male labour market characteristics: couples are more likely to migrate to rural LGAs when the male is out-of-the-labour force, and less likely to do so when the male is currently unemployed. Furthermore, the results presented in column 3 of panel D suggest no significant relationship between the migration and female member's share of household income.

\section{Conclusion}

We analyse the migration movements of power couples, half power and no-power couples within Australia between 2002 and 2008. We also address potential correlation of these movements with local labour market features.

We do not find evidence suggesting females are tied-movers in migration decisions for Australian couples. Power couples appear to be the most likely to migrate, however, unlike Compton and Pollack (2007) we find this relationship to be significant and similar for both male half-power couples and female half-power 
couples. Furthermore, when the probability of migration is found to be significantly associated with gender specific variables these tend to be the female local labour market measures. Rather than being a tied-mover, we could interpret these findings as suggesting that females who are not well matched in the local labour market are successfully migrating the couple.

We also do not find significant flows of power couples from rural or urban areas to large cities. The statistical insignificance of the parameter estimates associated with the labour market composition of the place of origin does support this prediction of Costa and Kahn (2000).

Taken together, our results support the urbanisation hypothesis for couples: partnered college graduates in Australia like to live in major cities regardless of their gender or the qualifications of their partner.

\section{References}

Akerlof, G.A. and Kranton, R.E. (2000) Economics and identity. The Quarterly Journal of Economics 115(3): 715-753.

Akerlof, G.A. and Kranton, R.E. (2010) Identity economics: How Our Identities Affect Our Work, Wages, and Well-being. (Princeton: Princeton University Press.)

Becker, G.S. (1962) Investment in human capital: A theoretical analysis. Journal of Political Economy 70; 9-49.

Becker, G.S. (1964) Human Capital: A Theoretical and Empirical Analysis, with Special Reference to Education (The University of Chicago Press, Chicago).

Bertrand, M., Kamenica, E. and Jessica Pan, J. (2015) Gender identity and relative income within households. The Quarterly Journal of Economics 130(2): 571614.

Blackburn, M.L. (2010) Internal migration and the earnings of married couples in the United States. Journal of Economic Geography 10: 87-111.

Central Intelligence Agency (2014) The World Factbook: Field listing urbanization. https://www.cia.gov/library/publications/the-world-factbook/fields/2212.html downloaded on 30/04/2015.

Chzhen, Y. Mumford, K.A. and Nicodema, C. (2013) The Gender Pay Gap in the Australian Private Sector: Is Selection Relevant Across the Wage Distribution. Economic Record 89(286): 367-381.

Compton, J. and Pollack, R.A. (2007) Why are power couples increasingly concentrated in large metropolitan areas? Journal of Labor Economics 25: 475-512.

Costa, D.L. and Kahn, M.E. (2000) Power couples; Changes in the locational choice of the college educated, 1940-90. The Quarterly Journal of Economics 115:1287-1315.

Goldin, C. and Katz L.F. (2008) Transitions: Career and family lifecycles of the educational elite. AEA Papers and Proceedings. 98:363-369. 
Hugo, G. and Harris, K. (2011) Population distribution effects of migration in Australia: Report for the Department of Immigration and Citizenship. (Canberra, Australia).

IMF (International Monetary Fund). (2009). World Economic Outlook - April 2009: Crisis and Recovery. World Economic and Financial Surveys. http://www.imf.org/external/pubs/ft/weo/2009/01/pdf/text.pdf Retrieved 27 September 2013.

Junankar, P.N. (2014) The Impact of the Global Financial Crisis on Youth Labour Markets. IZA DP No. 8400.

Mariotti, F., Mumford, K.A., and Pena-Boquete, Y. (2015) Household Asset Holding Diversification in Australia. Australian Economic Review 48(1): 43-64.

Mincer, J. (1978) Family migration decisions. Journal of Political Economy 86:749773.

Robins, J., Rotnitzky, A. and Zhao, L.P., (1995), Analysis of semiparametric regression models for repeated outcomes in the presence of missing data, Journal of the American Statistical Association, 90, 106-121.

Summerfield, M., Freidin, S., Hahn, M., Ittak, P., Li, N., Macalalad, N., Watson, N., Wilkins, R. and Wooden, M. (2013) HILDA User Manual - Release 12. Melbourne Institute of Applied Economic and Social Research, University of Melbourne, Australia.

Vella, F. (1998) Estimating models with sample selection bias: A survey. Journal of Human Resources 34(2): 441-457.

Wooldridge, J.M., (2002a), Inverse probability weighted M-estimators for sample selection, attrition and stratification, Portuguese Economic Journal, 1, 117-139.

Wooldridge, J.M., (2002b), Econometric analysis of cross-section and panel data, Cambridge, MA: The MIT Press. 


\section{Male}

Education (years)

(1) Full sample

(2) Power Couple

(3) Male Power

Over education

LGA unemployment rate

LGA job market insecurity

Mean

S.Dev.

Mean S.Dev.

Mean S.Dev.

Employed

12.83

2.73

16.65

2.18

16.25

1.97

$0.18 \quad 1.91$

$1.72 \quad 2.33$

1.59

2.17

0.05

0.04

$0.05 \quad 0.04$

0.05

0.03

12.03

5.13

12.22

4.17

11.98

4.85

Unemployed

0.93

0.97

0.97

0.02

0.01

0.01

0.05

0.02

0.02

\section{Female}

Education (years)

Over education

LGA unemployment rate

LGA job market insecurity

Employed

$\begin{array}{ll}13.04 & 2.56 \\ 0.38 & 1.88 \\ 0.05 & 0.04 \\ 11.02 & 6.45 \\ 0.73 & \\ 0.03 & \\ 0.24 & \end{array}$

$\begin{array}{ll}16.44 & 1.90 \\ 1.81 & 2.34 \\ 0.04 & 0.03 \\ 11.52 & 5.99 \\ 0.84 & \\ 0.01 & \\ 0.15 & \end{array}$

$11.95 \quad 1.10$

$-0.41 \quad 1.40$

$0.05 \quad 0.06$

$11.17 \quad 5.25$

0.68

0.02

0.30

Unemployed

Not in labour force

$\begin{array}{llll}3.37 & 1.19 & 3.17 & 1.08 \\ 35.74 & 7.47 & 36.15 & 6.57 \\ 12.93 & 2.26 & 16.54 & 1.60 \\ 1.26 & 1.17 & 1.12 & 1.08 \\ 73.48 & 39.08 & 98.54 & 46.85 \\ 0.32 & 0.25 & 0.36 & 0.22 \\ 0.30 & & 0.41 & \\ 0.72 & & 0.77 & \end{array}$

$3.44 \quad 1.16$

$37.34 \quad 6.87$

$14.10 \quad 1.14$

Education (couple average)

Dependent children

Disposable income (\$1000)

Female income share

Foreign

0.72

0.77

$1.32 \quad 1.15$

$82.19 \quad 44.58$

$0.24 \quad 0.21$

Home owners

0.77 
Table 2. Selected descriptive statistics, continued.

\begin{tabular}{|c|c|c|c|c|}
\hline & \multicolumn{2}{|c|}{ (4) Female Power } & \multicolumn{2}{|c|}{ (5) No-power Couple } \\
\hline & Mean & S.Dev. & Mean & S.Dev. \\
\hline \multicolumn{5}{|l|}{ Male } \\
\hline Education (years) & 11.76 & 1.11 & 11.34 & 1.24 \\
\hline Over education & -0.61 & 1.54 & -0.34 & 1.32 \\
\hline LGA unemployment rate & 0.05 & 0.05 & 0.06 & 0.04 \\
\hline LGA job market insecurity & 12.26 & 4.99 & 11.91 & 5.46 \\
\hline Employed & 0.94 & & 0.91 & \\
\hline Unemployed & 0.02 & & 0.03 & \\
\hline Not in labour force & 0.04 & & 0.07 & \\
\hline \multicolumn{5}{|l|}{ Female } \\
\hline Education (years) & 15.72 & 1.45 & 11.48 & 1.21 \\
\hline Over education & 1.56 & 1.87 & -0.23 & 1.32 \\
\hline LGA unemployment rate & 0.05 & 0.03 & 0.05 & 0.04 \\
\hline LGA job market insecurity & 11.24 & 7.08 & 10.78 & 6.58 \\
\hline Employed & 0.82 & & 0.69 & \\
\hline Unemployed & 0.01 & & 0.03 & \\
\hline Not in labour force & 0.17 & & 0.28 & \\
\hline \multicolumn{5}{|l|}{ Household } \\
\hline Size & 3.17 & 1.13 & 3.47 & 1.24 \\
\hline Age (couple average) & 35.76 & 7.04 & 35.33 & 7.89 \\
\hline Education (couple average) & 13.74 & 0.97 & 11.41 & 0.96 \\
\hline Dependent children & 1.09 & 1.10 & 1.33 & 1.21 \\
\hline Disposable income $(\$ 1000)$ & 77.32 & 39.15 & 63.26 & 30.44 \\
\hline Female income share & 0.41 & 0.26 & 0.30 & 0.26 \\
\hline Foreign & 0.31 & & 0.25 & \\
\hline Home owners & 0.77 & & 0.68 & \\
\hline Observations & 1545 & & 5831 & \\
\hline
\end{tabular}


Table 3. Migration probability (Probit), Base model.

\begin{tabular}{|c|c|c|c|}
\hline & $\begin{array}{c}\text { Probit Without } \\
\text { Sample } \\
\text { Selection } \\
\text { Controls } \\
\end{array}$ & $\begin{array}{l}\text { Probit: Test } \\
\text { for Sample } \\
\text { Selection } \\
\text { (base model) }\end{array}$ & IPW-Probit \\
\hline & $(\mathrm{A})$ & (B) & (C) \\
\hline \multirow[t]{2}{*}{ Power couple } & $0.285^{*}$ & $0.363^{*}$ & $0.279 *$ \\
\hline & $(0.060)$ & $(0.062)$ & $(0.061)$ \\
\hline \multirow[t]{2}{*}{ Male-power couple } & $0.231 *$ & $0.265^{*}$ & $0.240 *$ \\
\hline & $(0.075)$ & $(0.075)$ & $(0.077)$ \\
\hline \multirow[t]{2}{*}{ Female-power couple } & $0.218 *$ & $0.267 *$ & $0.202^{*}$ \\
\hline & $(0.058)$ & $(0.059)$ & $(0.059)$ \\
\hline \multirow[t]{2}{*}{ Origin - Large LGA } & -0.043 & -0.042 & -0.042 \\
\hline & $(0.046)$ & $(0.047)$ & $(0.048)$ \\
\hline \multirow[t]{2}{*}{ Origin - Rural LGA } & -0.125 & -0.121 & -0.124 \\
\hline & $(0.066)$ & $(0.068)$ & $(0.068)$ \\
\hline \multirow[t]{2}{*}{ Age (male) } & $0.052 *$ & 0.039 & $0.049 *$ \\
\hline & $(0.021)$ & $(0.022)$ & $(0.022)$ \\
\hline \multirow[t]{2}{*}{$\operatorname{Age}^{\wedge} 2$ (male) } & $-0.0007 *$ & $-0.0006 *$ & $-0.0007 *$ \\
\hline & $(0.0003)$ & $(0.0003)$ & $(0.0003)$ \\
\hline \multirow[t]{2}{*}{ Age (female) } & -0.015 & -0.025 & -0.020 \\
\hline & $(0.025)$ & $(0.025)$ & $(0.025)$ \\
\hline \multirow[t]{2}{*}{$\operatorname{Age}^{\wedge} 2$ (female) } & 0.00001 & 0.0001 & 0.00007 \\
\hline & $(0.0004)$ & $(0.0003)$ & $(0.0004)$ \\
\hline \multirow[t]{2}{*}{ Over-education (female) } & -0.005 & -0.005 & -0.005 \\
\hline & $(0.040)$ & $(0.041)$ & $(0.041)$ \\
\hline \multirow[t]{2}{*}{ Over-education (male) } & $-0.148 *$ & $-0.157 *$ & $-0.151 *$ \\
\hline & $(0.042)$ & $(0.042)$ & $(0.043)$ \\
\hline \multirow[t]{2}{*}{ Dependent children } & -0.042 & 0.004 & -0.073 \\
\hline & $(0.047)$ & $(0.047)$ & $(0.047)$ \\
\hline \multirow[t]{2}{*}{ Foreign } & 0.070 & 0.071 & 0.080 \\
\hline & $(0.044)$ & $(0.044)$ & $(0.045)$ \\
\hline \multirow[t]{2}{*}{ Home ownership } & $-0.517 *$ & $-0.525 *$ & $-0.536 *$ \\
\hline & $(0.046)$ & $(0.046)$ & $(0.047)$ \\
\hline \multirow[t]{2}{*}{$\lambda$} & & $0.786^{*}$ & \\
\hline & & $(0.091)$ & \\
\hline
\end{tabular}


Table 4. Migration probability (Probit) selected marginal effects

\begin{tabular}{|c|c|c|c|c|}
\hline & $\begin{array}{l}\text { Base model } \\
\text { (A) }\end{array}$ & (B) & $(\mathrm{C})$ & (D) \\
\hline Power couple & $\begin{array}{l}\mathbf{0 . 0 4 3}^{*} \\
(0.000)\end{array}$ & $\begin{array}{l}\mathbf{0 . 0 4 3}^{*} \\
(0.000)\end{array}$ & $\begin{array}{l}\mathbf{0 . 0 4 4} * \\
(0.000)\end{array}$ & $\begin{array}{l}\mathbf{0 . 0 4 3}^{*} \\
(0.000)\end{array}$ \\
\hline Male-power couple & $\begin{array}{l}\mathbf{0 . 0 3 7 *} \\
(0.002)\end{array}$ & $\begin{array}{l}\mathbf{0 . 0 3 7 *} \\
(0.001)\end{array}$ & $\begin{array}{l}\mathbf{0 . 0 3 6 *} \\
(0.002)\end{array}$ & $\begin{array}{l}\mathbf{0 . 0 3 1} * \\
(0.007)\end{array}$ \\
\hline Female-power couple & $\begin{array}{l}\text { 0.030* } \\
(0.001)\end{array}$ & $\begin{array}{l}\mathbf{0 . 0 3 0 *} \\
(0.001)\end{array}$ & $\begin{array}{l}\mathbf{0 . 0 3 1 *} \\
(0.000)\end{array}$ & $\begin{array}{l}\mathbf{0 . 0 3 5}^{*} \\
(0.000)\end{array}$ \\
\hline Origin - Major City LGA & $\begin{array}{l}-0.006 \\
(0.387)\end{array}$ & $\begin{array}{l}-0.005 \\
(0.458)\end{array}$ & $\begin{array}{l}-0.004 \\
(0.488)\end{array}$ & $\begin{array}{l}-0.003 \\
(0.662)\end{array}$ \\
\hline Origin - Rural LGA & $\begin{array}{l}-0.015 \\
(0.069)\end{array}$ & $\begin{array}{l}-0.015 \\
(0.069)\end{array}$ & $\begin{array}{l}-0.016 \\
(0.069)\end{array}$ & $\begin{array}{l}-0.012 \\
(0.149)\end{array}$ \\
\hline $\begin{array}{l}\text { Labour market insecurity of } \\
\text { LGA of origin (male) }\end{array}$ & & $\begin{array}{l}0.0007 \\
(0.179)\end{array}$ & & \\
\hline $\begin{array}{l}\text { Labour market insecurity of } \\
\text { LGA of origin (female) }\end{array}$ & & $\begin{array}{l}-\mathbf{- 0 . 0 0 1 *} \\
(0.024)\end{array}$ & & \\
\hline $\begin{array}{l}\text { Unemployment rate in LGA } \\
\text { of origin (male) } \\
\text { Unemployment rate in LGA } \\
\text { of origin (female) }\end{array}$ & & & $\begin{array}{c}-0.039 \\
(0.0523) \\
\mathbf{0 . 1 3 9 *} \\
(0.012)\end{array}$ & \\
\hline Unemployed (male) & & & & $\begin{array}{c}-0.018 \\
(0.228)\end{array}$ \\
\hline Out of labour force (male) & & & & $\begin{array}{c}0.010 \\
(0.437)\end{array}$ \\
\hline Unemployed (female) & & & & $\begin{array}{l}\mathbf{0 . 0 6 4 *} \\
(0.000)\end{array}$ \\
\hline Out of labour force (female) & & & & $\begin{array}{l}\mathbf{0 . 0 2 0} * \\
(0.020)\end{array}$ \\
\hline Disposable income $(\mathrm{x} 10,000)$ & & & & $\begin{array}{c}\mathbf{2 . 0 8}^{-7} * \\
(0.002)\end{array}$ \\
\hline Female income share & & & & $\begin{array}{c}0.005 \\
(0.697)\end{array}$ \\
\hline$\lambda$ & $\begin{array}{l}\mathbf{0 . 7 8 6 *} \\
(0.091)\end{array}$ & $\begin{array}{l}\mathbf{0 . 7 9 6}^{*} \\
(0.091)\end{array}$ & $\begin{array}{l}\mathbf{0 . 7 8 4} * \\
(0.091)\end{array}$ & $\begin{array}{l}\mathbf{0 . 7 8 8 *} \\
(0.094)\end{array}$ \\
\hline
\end{tabular}


Table 5. Migration probability by destination type (Multinomial Logit), selected results.

\begin{tabular}{|c|c|c|c|}
\hline & $\begin{array}{l}\text { Major City } \\
\text { LGA }\end{array}$ & $\begin{array}{l}\text { Urban } \\
\text { LGA }\end{array}$ & $\begin{array}{l}\text { Rural } \\
\text { LGA }\end{array}$ \\
\hline Panel A & (1) & (2) & (3) \\
\hline Power couple & $\begin{array}{c}2.048 \\
\mathbf{0 . 7 1 7 *} \\
(0.143)\end{array}$ & $\begin{array}{c}0.899 \\
-0.106 \\
(0.288)\end{array}$ & $\begin{array}{c}1.820 \\
0.599 \\
(0.326)\end{array}$ \\
\hline Male-power couple & $\begin{array}{c}\mathbf{2 . 0 0 4} \\
\mathbf{0 . 6 9 5 *} \\
(0.168)\end{array}$ & $\begin{array}{c}0.869 \\
-0.140 \\
(0.362)\end{array}$ & $\begin{array}{c}1.241 \\
0.216 \\
(0.514)\end{array}$ \\
\hline Female-power couple & $\begin{array}{c}\mathbf{1 . 7 2 3} \\
\mathbf{0 . 5 4 4} * \\
(0.147)\end{array}$ & $\begin{array}{c}1.347 \\
0.298 \\
(0.211)\end{array}$ & $\begin{array}{c}1.257 \\
0.229 \\
(0.275)\end{array}$ \\
\hline Origin Major City LGA & $\begin{array}{c}1.790 \\
\mathbf{0 . 5 8 2} * \\
(0.140)\end{array}$ & $\begin{array}{c}0.477 \\
\mathbf{- 0 . 7 4 0 *} \\
(0.172)\end{array}$ & $\begin{array}{c}\mathbf{0 . 3 2 2} \\
\mathbf{- 1 . 1 3 3} * \\
(0.246)\end{array}$ \\
\hline Origin Rural LGA & $\begin{array}{r}0.658 \\
-0.418 \\
(0.237) \\
\end{array}$ & $\begin{array}{c}0.835 \\
-0.180 \\
(0.212) \\
\end{array}$ & $\begin{array}{c}0.865 \\
-0.145 \\
(0.273) \\
\end{array}$ \\
\hline Panel B & & & \\
\hline Power couple & $\begin{array}{l}\mathbf{2 . 0 5 7} \\
\mathbf{0 . 7 2 1} * \\
(0.143)\end{array}$ & $\begin{array}{c}0.893 \\
-0.113 \\
(0.287)\end{array}$ & $\begin{array}{c}1.855 \\
0.618 \\
(0.330)\end{array}$ \\
\hline Male-power couple & $\begin{array}{c}\mathbf{2 . 0 1 8} \\
\mathbf{0 . 7 0 2} * \\
(0.168)\end{array}$ & $\begin{array}{c}0.887 \\
-0.120 \\
(0.363)\end{array}$ & $\begin{array}{c}1.261 \\
0.232 \\
(0.515)\end{array}$ \\
\hline Female-power couple & $\begin{array}{c}1.719 \\
\mathbf{0 . 5 4 2 *} \\
(0.148)\end{array}$ & $\begin{array}{c}1.357 \\
0.305 \\
(0.211)\end{array}$ & $\begin{array}{c}1.260 \\
0.231 \\
(0.274)\end{array}$ \\
\hline Origin Major City LGA & $\begin{array}{c}1.808 \\
\mathbf{0 . 5 9 2} * \\
(0.139)\end{array}$ & $\begin{array}{c}0.499 \\
\mathbf{- 0 . 6 9 5 *}^{*} \\
(0.176)\end{array}$ & $\begin{array}{c}0.313 \\
-\mathbf{1 . 1 6 2} * \\
(0.246)\end{array}$ \\
\hline Origin Rural LGA & $\begin{array}{c}0.663 \\
-0.411 \\
(0.237)\end{array}$ & $\begin{array}{c}0.829 \\
-0.188 \\
(0.210)\end{array}$ & $\begin{array}{c}0.897 \\
-0.109 \\
(0.274)\end{array}$ \\
\hline $\begin{array}{l}\text { Labour market } \\
\text { insecurity of LGA of } \\
\text { origin (male) } \\
\text { Labour market } \\
\text { insecurity of LGA of } \\
\text { origin (female) }\end{array}$ & $\begin{array}{c}1.015 \\
0.015 \\
(0.011) \\
0.983 \\
-0.017 \\
(0.009)\end{array}$ & $\begin{array}{c}1.011 \\
0.011 \\
(0.015) \\
\mathbf{0 . 9 6 6} \\
\mathbf{- 0 . 0 3 5 *}^{*} \\
(0.014) \\
\end{array}$ & $\begin{array}{c}2.743 \\
-0.002 \\
(0.017) \\
1.014 \\
0.014 \\
(0.011)\end{array}$ \\
\hline
\end{tabular}


Table 5. Migration probability by destination type (Multinomial Logit), selected results, continued.

\begin{tabular}{lccc}
\hline \hline & Major City & Urban & Rural \\
& LGA & LGA & LGA \\
\cline { 2 - 4 } & $(1)$ & $(2)$ & $(3)$ \\
\cline { 2 - 4 } Panel C & & & \\
Power couple & & & \\
& $\mathbf{2 . 0 5 6}$ & 0.893 & 1.855 \\
Male-power couple & $\mathbf{0 . 7 2 5 *}$ & -0.113 & 0.618 \\
& $(0.143)$ & $(0.287)$ & $(0.330)$ \\
Female-power couple & $\mathbf{2 . 0 0 2}$ & 0.835 & 1.163 \\
& $\mathbf{0 . 6 9 4}$ & -0.180 & 0.151 \\
& $(0.168)$ & $(0.358)$ & $(0.512)$ \\
Origin Major City LGA & $\mathbf{1 . 7 3 7}$ & 1.374 & 1.274 \\
& $\mathbf{0 . 5 5 2}$ & 0.318 & 0.242 \\
Origin Rural LGA & $(0.146)$ & $(0.210)$ & $(0.276)$ \\
& $\mathbf{1 . 7 3 7}$ & $\mathbf{0 . 5 0 0}$ & $\mathbf{0 . 3 2 8}$ \\
& $\mathbf{0 . 5 8 7 *}$ & $\mathbf{- 0 . 6 9 4 *}$ & $\mathbf{- 1 . 1 1 5 *}$ \\
& $(0.142)$ & $(0.172)$ & $(0.242)$ \\
Unemployment rate in & 0.653 & 0.847 & 0.840 \\
LGA of origin (male) & -0.427 & -0.166 & -0.175 \\
& $(0.239)$ & $(0.216)$ & $(0.279)$ \\
Unemployment rate in & & & \\
LGA of origin (female) & -1.057 & 2.470 & 0.068 \\
& $(1.336)$ & 0.904 & -2.687 \\
& 3.294 & $(1.236)$ & $(2.494)$ \\
& 1.192 & $\mathbf{1 5 . 2 8 7 *}$ & $\mathbf{1 4 . 5 5 6}$ \\
& $(1.002)$ & $\mathbf{2 . 7 2 7}$ & $\mathbf{2 . 6 7 8}$ \\
& & $(0.757)$ & $(1.321)$ \\
\hline
\end{tabular}


Table 5. Migration probability by destination type - Multinomial Logit, selected results, continued.

\begin{tabular}{|c|c|c|c|}
\hline & $\begin{array}{c}\text { Major City } \\
\text { LGA }\end{array}$ & $\begin{array}{l}\text { Urban } \\
\text { LGA }\end{array}$ & $\begin{array}{l}\text { Rural } \\
\text { LGA }\end{array}$ \\
\hline & (1) & (2) & (3) \\
\hline Panel D & & & \\
\hline Power couple & 1.939 & 1.062 & 1.086 \\
\hline & $0.662 *$ & 0.060 & 0.802 \\
\hline & $(0.153)$ & $(0.303)$ & $(0.342)$ \\
\hline Male-power couple & 1.893 & 0.908 & 1.336 \\
\hline & 0.638 & -0.097 & 0.290 \\
\hline & $(0.171)$ & $(0.366)$ & $(0.506)$ \\
\hline Female-power couple & 1.732 & 1.559 & 1.495 \\
\hline & $0.549 *$ & $0.444 *$ & 0.402 \\
\hline & $(0.151)$ & $(0.220)$ & $(0.285)$ \\
\hline Origin Major City LGA & 1.761 & 0.481 & 0.327 \\
\hline & $0.566^{*}$ & $-0.733 *$ & $-1.119 *$ \\
\hline & $(0.140)$ & $(0.174)$ & $(0.245)$ \\
\hline Origin Rural LGA & 0.670 & 0.850 & 0.869 \\
\hline & -0.401 & -0.162 & -0.140 \\
\hline & $(0.238)$ & $(0.214)$ & $(0.277)$ \\
\hline Unemployed (male) & 0.784 & 1.226 & $-0.632 e^{-6}$ \\
\hline & -0.243 & 0.204 & $-14.273^{*}$ \\
\hline & $(0.303)$ & $(0.367)$ & $(0.244)$ \\
\hline Out of labour force (male) & 0.917 & 1.644 & 2.954 \\
\hline & -0.087 & 0.497 & 1.083 \\
\hline & $(0.279)$ & $(0.283)$ & $(0.357)$ \\
\hline Unemployed (female) & 2.428 & 3.117 & 2.083 \\
\hline & $0.887 *$ & $1.137 *$ & 0.734 \\
\hline & $(0.239)$ & $(0.331)$ & $(0.556)$ \\
\hline Out of labour force (female) & 1.358 & 1.999 & 1.283 \\
\hline & $0.306^{*}$ & $0.693 *$ & 0.249 \\
\hline & $(0.144)$ & $(0.200)$ & $(0.297)$ \\
\hline HH Disposable income & 1.000 & 1.000 & 1.000 \\
\hline & $3.67 \mathrm{e}^{-6} *$ & $1.15 \mathrm{e}^{-6}$ & $1.89 \mathrm{e}^{-6}$ \\
\hline & $\left(1.03 \mathrm{e}^{-6}\right)$ & $\left(1.94 \mathrm{e}^{-6}\right)$ & $\left(3.37 \mathrm{e}^{-6}\right)$ \\
\hline Female income share & 1.181 & 1.362 & 0.781 \\
\hline & 0.166 & 0.309 & -0.247 \\
\hline & $(0.247)$ & $(0.335)$ & $(0.491)$ \\
\hline
\end{tabular}

HILDA Survey - Waves 2 to 8 (Pooled.) Relative risk ratios in italics, coefficient estimates are in standard text, standard errors reported in parenthesis, * denotes significance at $95 \%$ confidence. Standard errors are adjusted for clustering on household identifier. All estimates (in Panels A to D) include controls for the age (and age squared) of each couple member; each couple member's education relative to the LGA average for their occupation; the number of dependent children in the household, least one couple member being foreign born, and if the couple are home owners. 


\section{APPENDIX.}

Table A1. Migration probability by destination type (Multinomial Logit), Base model.

\begin{tabular}{|c|c|c|c|}
\hline & $\begin{array}{c}\text { Major City } \\
\text { LGA }\end{array}$ & $\begin{array}{l}\text { Urban } \\
\text { LGA }\end{array}$ & $\begin{array}{l}\text { Rural } \\
\text { LGA }\end{array}$ \\
\hline & (1) & $(2)$ & (3) \\
\hline \multirow[t]{2}{*}{ Power couple } & $0.717 *$ & -0.106 & 0.599 \\
\hline & $(0.143)$ & $(0.288)$ & $(0.326)$ \\
\hline \multirow[t]{2}{*}{ Male-power couple } & $0.695^{*}$ & -0.140 & 0.216 \\
\hline & $(0.168)$ & $(0.362)$ & $(0.514)$ \\
\hline \multirow[t]{2}{*}{ Female-power couple } & $0.544 *$ & 0.298 & 0.229 \\
\hline & $(0.147)$ & $(0.211)$ & $(0.275)$ \\
\hline \multirow[t]{2}{*}{ Origin - Large LGA } & $0.582 *$ & $-0.740 *$ & $-1.133 *$ \\
\hline & $(0.140)$ & $(0.172)$ & $(0.246)$ \\
\hline \multirow[t]{2}{*}{ Origin - Rural LGA } & -0.418 & -0.180 & -0.145 \\
\hline & $(0.237)$ & $(0.212)$ & $(0.273)$ \\
\hline \multirow[t]{2}{*}{ Age (male) } & 0.045 & $0.181 *$ & 0.210 \\
\hline & $(0.054)$ & $(0.079)$ & $(0.159)$ \\
\hline \multirow[t]{2}{*}{$\operatorname{Age}^{\wedge} 2($ male $)$} & -0.001 & -0.002 & -0.003 \\
\hline & $(0.001)$ & $(0.001)$ & $(0.002)$ \\
\hline \multirow[t]{2}{*}{ Age (female) } & -0.021 & -0.099 & 0.065 \\
\hline & $(0.064)$ & $(0.084)$ & $(0.173)$ \\
\hline \multirow[t]{2}{*}{$\operatorname{Age}^{\wedge} 2$ (female) } & 0.0004 & 0.001 & -0.001 \\
\hline & $(0.001)$ & $(0.001)$ & $(0.003)$ \\
\hline \multirow[t]{2}{*}{ Over-education (female) } & 0.088 & 0.035 & $-0.503 *$ \\
\hline & $(0.103)$ & $(0.159)$ & $(0.220)$ \\
\hline \multirow[t]{2}{*}{ Over-education (male) } & -0.101 & $-0.461 *$ & $-0.862 *$ \\
\hline & $(0.108)$ & $(0.164)$ & $(0.245)$ \\
\hline \multirow[t]{2}{*}{ Dependent children } & $-0.261 *$ & 0.195 & -0.082 \\
\hline & $(0.120)$ & $(0.190)$ & $(0.226)$ \\
\hline \multirow[t]{2}{*}{ Foreign } & $0.303^{*}$ & -0.125 & -0.213 \\
\hline & (0.106) & $(0.188)$ & $(0.257)$ \\
\hline \multirow[t]{2}{*}{ Home ownership } & $-0.983 *$ & $-1.435^{*}$ & $-0.648 *$ \\
\hline & $(0.117)$ & $(0.175)$ & $(0.241)$ \\
\hline
\end{tabular}

Standard errors are adjusted for clustering on household identifier. HILDA Survey - Waves 2 to 8 (Pooled) standard errors reported in parenthesis, * denotes significance at $95 \%$ confidence. 